\title{
1 Coproduction of transportation fuels 2 in advanced IGCCs via coal and 3 biomass mixtures
}

4

Qin Chen, Ashok Rao ${ }^{1}$, and Scott Samuelsen

Advanced Power and Energy Program, University of California, Irvine, CA 92697-3550, USA

\section{Abstract}

Converting abundant fossil resources of coal to alternative transportation fuels is a promising option for countries heavily dependent on petroleum imports if plants are equipped with carbon capture for sequestration and cofed with biomass ( $30 \%$ by weight of the total feed on a dry basis), an essentially carbon neutral fuel, without penalizing the process economics excessively. A potential exists to improve both thermal efficiency and economics of such plants by taking advantage of the synergies of coproducing electricity using advanced technologies under development. Three types of transportation fuels are considered. Fischer-Tropsch (F-T) liquids consisting predominantly of waxes could be processed in existing refineries while displacing petroleum and the refined products introduced into the market place at the present time or in the near term without requiring changes to the existing infrastructure. Ethanol could potentially serve in the not so distant future (or phased in by blending with conventional liquid fuels). Hydrogen which could play a dominant role in the more distant future being especially suitable to the fuel cell hybrid vehicle (FCHV). Two types of coal along with biomass cofeed are

\footnotetext{
${ }^{1}$ Corresponding author. Tel.: +1 949824 7302; fax: +1 9498247423.
}

E-mail address: adr@apep.uci.edu 
22 evaluated; bituminous coal at $\$ 42.0 /$ dry tonne, lignite at $\$ 12.0 /$ dry tonne, and switchgrass at

$23 \$ 99.0 /$ dry tonne. The calculated cost for F-T liquids ranged from $\$ 77.8 / \mathrm{bbl}$ to $\$ 86.6 / \mathrm{bbl}$ (or

$24 \$ 0.0177$ to $0.0197 / \mathrm{MJ}$ LHV) depending on the feedstock, which is comparable to the projected

25 longer term market price of crude oil at $\sim \$ 80 / \mathrm{bbl}$ when supply and demand reach a new

26 equilibrium [Lafakis. Moody's Analytics. http://money.cnn.com/2015/01/09/investing/oil-price-

27 bottom/index.html (accessed on 1-12-15)][1] (or $\sim \$ 0.0172 / \mathrm{MJ}$ LHV). It should be noted,

28 however, that F-T liquids contain no sulfur or nitrogen compounds and no inorganics. The

29 calculated cost of fuel grade ethanol ranged from $\$ 4.84$ to $4.91 /$ gal (or $\$ 0.0566$ to $0.0582 / \mathrm{MJ}$

30 LHV), while the price of gasoline in the U.S. amounted to $\$ 0.0240$ to $0.0279 / \mathrm{MJ}$ LHV when crude

31 oil was at $\sim \$ 80 / \mathrm{bbl}$. Ethanol coproduction may not appear to be as attractive as the other

32 options at these scales, primarily due to the much lower plant efficiency. However, from a life

33 cycle greenhouse gas emissions standpoint, ethanol produced with biomass cofeeding and CCS,

34 have a lower carbon footprint than gasoline or diesel, especially when derived from petroleum.

35 The calculated cost of hydrogen ranged from $\$ 1.87$ to $2.13 / \mathrm{kg}$ (or $\$ 0.0156$ to $0.0177 / \mathrm{MJ} \mathrm{LHV}$ ),

36 which is significantly lower than the DoE announced goal of $\$ 3.00 / \mathrm{kg}$ in 2005 .

\section{Keywords}

38 IGCC, biomass, hydrogen, Fischer-Tropsch, ethanol

\section{Nomenclature and acronyms}

$\begin{array}{lll}40 & \text { ASU } & \text { air separation unit } \\ 41 & \text { bbl } & \text { "blue" barrel (42 gallons) } \\ 42 & \text { BFW } & \text { boiler feed water } \\ 43 & \text { CCS } & \text { carbon capture and storage } \\ 44 & \text { COE } & \text { cost of electricity } \\ 45 & \text { DoE } & \text { Department of Energy } \\ 46 & \text { FCHV } & \text { fuel cell hybrid vehicle } \\ 47 & \text { F-T } & \text { Fischer-Tropsch }\end{array}$




$\begin{array}{lll}48 & \text { HHV } & \text { higher heating value } \\ 49 & \text { HRSG } & \text { heat recovery steam generator } \\ 50 & \text { IGCC } & \text { integrated gasification combined cycle } \\ 51 & \text { ISO } & \text { international organization for standardization } \\ 52 & \text { ITM } & \text { ion transport membrane } \\ 53 & \text { LHV } & \text { lower heating value } \\ 54 & \text { LP, MP, IP, HP } & \text { low, medium, intermediate, high pressure } \\ 55 & \text { tonne } & \text { metric ton (1000 kg) } \\ 56 & \text { ppmw } & \text { parts per million by weight } \\ 57 & \text { ppmv } & \text { parts per million by volume } \\ 58 & \text { PSA } & \text { pressure swing adsorption } \\ 59 & \text { RPS } & \text { Renewable Portfolio Standard } \\ 60 & \text { SMR } & \text { steam methane reforming } \\ 61 & \text { ST } & \text { short ton } \\ 62 & \text { TPC } & \text { total plant cost } \\ 63 & & \end{array}$

\section{Introduction}

Coal is a primary energy source with world consumption of this fossil fuel being 162 quadrillion $\mathrm{kJ}$ in 2012 accounting for $28.5 \%$ of total energy consumption on a world-wide basis.

67 Furthermore, it is projected to increase to 232 quadrillion $\mathrm{kJ}$ and is expected to maintain a

68 similar share of the total energy consumption in 2040. In the power generation sector, coal-fired

69 plants generated 8.4 trillion kWh of electricity in 2012 or $39.4 \%$ of total world electricity

70 generation while 13.9 trillion KWh of electricity or $35.6 \%$ of total world electricity generation is

71 projected to be generated by coal-based plants in 2040 [2]. Coal-fired power plants are the

72 major emitters of $\mathrm{CO}_{2}$ emissions, and various other pollutants, such as particulate matter, sulfur

73 oxides, nitrogen oxides and mercury. For example, the U.S. emitted 5,290 million tonne of $\mathrm{CO}_{2}$

74 in 2012 with electrical power generation accounting for $38.5 \%$ of the $\mathrm{CO}_{2}$ emissions [3].

75 Integrated gasification combined cycle (IGCC) power plants are a clean approach for utilizing

76 coal [4]. IGCC plants designed for carbon capture shift the CO in the syngas generated by

77 gasification of the feedstock to $\mathrm{CO}_{2}$ by reaction with steam while forming $\mathrm{H}_{2}$, separating out the

$78 \mathrm{CO}_{2}$ and combusting the decarbonized clean syngas in the gas turbine of the combined cycle. 
79 Since the gas produced by gasification contains $\mathrm{CO}$ and $\mathrm{H}_{2}$, which are the building blocks for a

80 host of coproducts, a potential exists to synergistically combine electricity generation along with

81 synthesis of a coproduct $[4,5,6]$.

Biomass utilization in power generation has been gaining increasing attention due to its

83 near carbon neutral benefit while political level regulations such as the Renewable Portfolio

84 Standard (RPS) in the U.S. is accelerating this trend [7]. In particular, California is to achieve $33 \%$

85 of renewables as its energy source by 2020 per the California Energy Commission [8]. State-of-

86 the-art gasifiers capable of cofeeding biomass along with coal are available $[9,10]$. promising option for countries heavily dependent on petroleum imports except that the carbon

89 footprint of such plants can be excessive. Equipping such plants with carbon capture for 90 sequestration and cofeeding biomass can overcome this environmental barrier if the captured

$91 \mathrm{CO}_{2}$ can be sequestered in a safe and reliable manner without penalizing the process economics

92 excessively. A potential exists to improve both thermal efficiency and economics of such plants

93 by taking advantage of the synergies of coproducing electricity, the specific amount of $\mathrm{CO}_{2}$

94 generated being inversely proportional to efficiency. Use of advanced technologies under

95 development would further improve the plant thermal efficiency and economics.

97 membrane based air separation $[11,12]$ to separate $\mathrm{O}_{2}$ at high temperatures, warm gas cleanup

98 processes to remove pollutants and $\mathrm{CO}_{2}$ at relatively high temperatures $[13,14]$, and advanced

99 gas turbines to serve as high efficiency power generators [15]. In order to fully realize the

100 benefits of these advanced technologies, it is imperative to identify plant integration concepts 
101 that not only improve the efficiency of one single unit of the plant, but also provide synergistic 102 enhancement of the overall plant efficiency and process economics.

This paper investigates conceptual designs using these above feedstock blends and the 104 advanced technologies for IGCC plants designed with CCS to assess the coproduction of three 105 types of transportation fuels suitable for introduction into the market place at different time

106 frames. F-T liquids could be processed in existing refineries while displacing petroleum and the 107 refined products introduced into the market place at the present time or in the near term 108 without requiring changes to the existing infrastructure. Fuel grade ethanol $(97.7$ mole \% 109 ethanol mixed with other alcohols resulting in an average carbon number of 2.01) could 110 potentially serve in the not so distant future or could be phased in by blending with

111 conventional liquid fuels. Hydrogen could play a dominant role in the more distant future being 112 especially suitable to the FCHV. A number of system studies have been conducted to evaluate 113 the merits of coproduction from coal $[15,16,17,18,19,20,21,22]$ but our paper focusses on 114 the coproduction of three transportation fuels on a consistent basis to bridge the near term to 115 the future while utilizing environmentally sustainable biomass as a cofeed and advanced 116 technology under development.

\section{Approach}

118 About half the coal produced in the U.S. is bituminous with carbon content 119 approximately ranging from $65 \%$ to $85 \%$ resulting in a high energy density. Lignite is another 120 major coal resource despite its much lower energy density, and accounts for about $7 \%$ of total 121 U.S. produced coal [23]. Due to the significant differences in heating value, ash, sulfur and 122 moisture content between the two types of coals, plant performance and costs can differ 123 significantly, and these two major coal types cover each end of the spectrum. Illinois No. 6 is 
124 utilized as representative of the bituminous coal while the lignite is from N. Dakota. All data

125 presented for these feedstocks except that for the Hg content of Illinois No. 6 coal and Cl

126 content of N. Dakota lignite are taken from U.S. Department of Energy (DoE) Funding

127 Opportunity Number: DE-FOA0000496 [24]. Data for the switchgrass is obtained from DoE/NETL

128 Report 2012/1546 [25]. The moisture content for the switchgrass corresponds to covered field

129 drying. Table 1 presents the coal and biomass ultimate analyses and heating value data. The

130 proposed amount of biomass in the cofeed cases is $30 \%$ of the total feed on a dry weight basis

131 based on successful operation of the Shell gasifier with coal and biomass mixtures [26].

Herbaceous energy crops such as switchgrass grown on purpose can provide constant

133 and significant supply of the biomass resource. Switchgrass which is a fast growing crops has

134 been successfully utilized in gasification facilities [27] and can be grown on marginal or degraded

135 lands and avoid competition over agricultural lands, as promoted by the Conservation Reserve

136 Program (CRP) [28] led by the U.S. Department of Agriculture (USDA) Natural Resources

137 Conservation Service (NRCS). Cofeeding biomass along with coal appears to be a strategy for

138 building large scale gasification plants which can take advantage of economies of scale.

139 Furthermore, this strategy can circumvent any seasonal variability in the supply of biomass; the

140 coal rate may be increased to compensate for the reduction in biomass supply as long as the

141 feed handling system is properly designed.

Ambient conditions can have a significant effect on the performance and economics of

143 power plants, especially gas turbine based, and it is essential that site specific conditions be

144 specified. ISO ambient conditions are chosen to be representative for Illinois No. 6 bituminous

145 coal case site, i.e., $15^{\circ} \mathrm{C}$ dry bulb temperature, $60 \%$ relative humidity, and sea-level barometric

146 pressure. Since the lignite is from N. Dakota and lignite is typically not transported over 
147 significant distances due to its much lower energy density, site ambient conditions more specific

148 to N. Dakota are specified consisting of $4.4^{\circ} \mathrm{C}$ dry bulb temperature, $40 \%$ relative humidity, and

149 elevation of $579 \mathrm{~m}$ above sea level, the corresponding lower barometric pressure ends up

150 derating the gas turbine power output due to the lower air density.

151 Coal only IGCC plants without coproduction, developed to establish the cost of

152 electricity for use in the economic analysis of the coproduction cases, capture $90 \%$ of the carbon

153 present in the particulate free syngas. Biomass cofed cases "capture" $80 \%$ of the carbon (in the

154 form of $\mathrm{CO}_{2}$ for CCS and as carbon in the coproduct) in the particulate free syngas to take credit

155 for the renewable nature of the biomass feedstock, consistent with basis defined in DoE Funding

156 Opportunity Number: DE-FOA0000496 [24]. Even with this lower amount of capture for biomass

157 cofed cases (which are cofed with $30 \%$ by weight of the total feed as biomass on a dry basis) a

158 substantially lower $\mathrm{CO}_{2}$ emission on a net $\mathrm{MW}$ basis is realized.

159 Coproduced F-T Liquids are stabilized but not refined and will have to be shipped to a

160 refinery for further processing; the ethanol is made as fuel grade mixed alcohols; and the

161 hydrogen is specified to be suitable for FCHV quality with molar purity of $99.99 \%$.

The criteria used in setting the split between electricity and coproduct in each case is:

$$
\frac{\text { Net MW } \times 3.6 \times 10^{6} \mathrm{KJ} / \mathrm{MWh}}{\text { Net MW } \times 3.6 \times 10^{6} \mathrm{KJ} / \mathrm{MWh}+\mathrm{KJ} / \mathrm{h} \mathrm{HHV} \mathrm{Coproduct}}=50 \%
$$

163 A split of $\geq 50 \%$ split was stipulated by the DoE who funded this project. For this study, the split 164 was set at $50 \%$ for each case but it should be noted that this split could have a significant effect 165 on the overall plant economics and a future study is recommended to optimize its value. 


\section{Plant configuration and integration concepts}

The plants are configured with promising technologies under development with the main objective being to improve not only the performance of individual plant subsections but

169 also the overall plant cost by identifying synergistic thermal integration of different plant

170 subsections. Table 2 summarizes the technologies selected for major plant subsections for the 171 gasification island and for the coproduction units. Technologies for the gasification island and

172 their integration concepts are discussed in detail in a previous paper by the authors [29]. The

173 plant steady state simulations are performed on Aspen Plus ${ }^{\circledR}$, a process engineering flow sheet

174 modeling system offered by AspenTech using thermodynamic models with appropriate

175 approaches to equilibrium. The advanced technologies such as the ITM, syngas desulfurization

176 and decarbonization, and ethanol synthesis using Rh based catalyst are under development.

177 These systems were modeled using smaller scale test data and thus uncertainty exists on how 178 the performance or yields would scale-up.

\subsection{Electricity only}

The resulting overall process scheme for the electricity only IGCC plants with CCS is

181 depicted in Fig. 1 and only the advanced technology subsystems are described in the following.

182 Air Separation Unit (ASU). $\mathrm{O}_{2}$ is separated from air using a high temperature ion transport

183 membrane (ITM) which allows permeation of oxygen in ionic form. ITMs are projected to

184 provide a $30 \%$ reduction in both power consumption and capital cost when compared to the

185 conventional cryogenic unit. Feed air to this unit is extracted from the gas turbine compressor,

186 further compressed to 25.7 bar in a booster compressor, and then heated up in an interchanger

187 against the depleted air stream from the ITM followed by further heating to $850^{\circ} \mathrm{C}$ by directly

188 firing decarbonized syngas into the air stream. It then enters the ITM unit which is modeled 
190 is cooled in a heat recovery steam generator (HRSG) while generating high pressure (HP),

191 intermediate pressure (IP) and low pressure (LP) steam. Finally it is cooled against cooling water

192 and then compressed by a multistage intercooled compressor before it is provided to the

193 gasifier, while non-permeate oxygen-depleted air is recycled back to the gas turbine. Some $\mathrm{O}_{2}$ is

194 also provided to $\mathrm{a}_{2} \mathrm{SO}_{4}$ unit which produces this saleable byproduct from the sulfur

195 compounds separated out from the syngas

196 Gasification and Syngas Cleanup. The dry feedstock is transported by $\mathrm{CO}_{2}$ since there is no $\mathrm{N}_{2}$

197 available (in a conventional IGCC utilizing a cryogenic ASU, high purity $\mathrm{N}_{2}$ can be provided) and is

198 fed to the gasifiers along with $\mathrm{O}_{2}$ and steam via a top-mounted feed injector. Almost complete

199 conversion (99.5\%) of feedstock carbon occurs at a temperature of $1300^{\circ} \mathrm{C}$ to $1400^{\circ} \mathrm{C}$. Hot raw

200 syngas and liquid slag are discharged from the gasifier reaction chamber and the raw gas is

201 cooled to $677^{\circ} \mathrm{C}$ in a radiant syngas cooler while generating HP steam. Coarser particulates are

202 removed from raw syngas by barrier filter operating at this same temperature of $677^{\circ} \mathrm{C}[31]$,

203 followed by scrubbing with recycled water to remove water soluble components including

204 alkalis and halides. The slag discharges into a water bath at the bottom of the radiant syngas

205 cooler and is cooled to temperatures of $\sim 220^{\circ} \mathrm{C}$ and the molten slag solidifies to an

206 environmentally benign nonleachable vitrified granulate. The syngas now at $189^{\circ} \mathrm{C}$ is then

207 preheated in a feed/effluent interchanger and desulfurized by the regenerable $\mathrm{ZnO}$ process such

208 as that developed by RTI[13] by the overall reactions: $\mathrm{H}_{2} \mathrm{~S}+\mathrm{ZnO}=\mathrm{ZnS}+\mathrm{H}_{2} \mathrm{O}$ and $\mathrm{COS}+\mathrm{ZnO}=$

$209 \mathrm{ZnS}+\mathrm{CO}_{2} \sim 260^{\circ} \mathrm{C}$, a temperature much higher than that of a conventional desulfurization

210 process which requires cooling of the feed gas to near ambient temperatures causing both

211 efficiency and plant cost penalties. The regenerator off-gas containing $\mathrm{SO}_{2}$ obtained by the

212 reaction: $\mathrm{ZnS}+\mathrm{O}_{2}=\mathrm{ZnO}+\mathrm{SO}_{2}$, is fed to a $\mathrm{H}_{2} \mathrm{SO}_{4}$ unit to produce a saleable byproduct. The 
213 desulfurized syngas after cooling in the feed/effluent interchanger enters fixed-bed sorption

214 process such as that developed by TDA [32] for $\mathrm{Hg}$ removal. Some of the $\mathrm{NH}_{3}$ and $\mathrm{HCN}$ are also

215 captured by this sorbent.

216 Syngas Shifting and Decarbonization. The purpose of this unit is to convert most of the CO in the

217 syngas to $\mathrm{H}_{2}$ by means of the water gas shift reaction: $\mathrm{CO}+\mathrm{H}_{2} \mathrm{O}=\mathrm{H}_{2}+\mathrm{CO}_{2}$. This conversion step

218 is crucial to the overall carbon capture of the IGCC plant. $\mathrm{NH}_{3}$ in the feed passes through the

219 shift reactor unchanged and without affecting the catalyst performance. On the other hand,

$220 \mathrm{HCN}$ will be hydrogenated to $\mathrm{CH}_{4}$ and $\mathrm{N}_{2}$. Sufficient steam is injected into the syngas and then

221 fed to the shift unit. The heat evolved by the exothermic shift reaction is used to generate steam.

222 The shifted syngas at a temperature of $\sim 200^{\circ} \mathrm{C}$ is combined with recycle gas exiting the $\mathrm{CO}_{2}$

223 purification unit and then fed to the TDA fixed-bed sorption unit [14, 33] for decarbonizing the

224 syngas. Regeneration of the sorbent is accomplished utilizing steam. The mixture consisting of

225 desorbed $\mathrm{CO}_{2}$, steam and residual syngas is cooled in a series of heat exchangers consisting of

226 generating LP steam, vacuum condensate/makeup boiler feed water (BFW) heating and finally

227 trim cooling against cooling water. The gas is then compressed, cooled while recovering bulk of

228 the heat for vacuum condensate/makeup BFW heating, dehydrated and fed to a purification

229 unit. The purification may be done cryogenically or simply fed to a catalytic oxidizer to burn off

230 the combustibles present in this crude $\mathrm{CO}_{2}$ stream depending on the required $\mathrm{Ar}$ content of the

231 final $\mathrm{CO}_{2}$ product. The purified $\mathrm{CO}_{2}$ stream is then split into fractions as required for in-plant

232 usage (such as gasifier feed transport), and pressurized to the required pressures. The

233 decarbonized syngas leaving the adsorption unit at a temperature of $\sim 250^{\circ} \mathrm{C}$ with its

234 accompanying steam is supplied to the gas turbine along with the depleted air from the ASU.

235 The accompany steam provides additional motive fluid in the turbine as well as a thermal

236 diluent to reduce the flame temperature in the gas turbine combustor and thus $\mathrm{NO}_{\mathrm{x}}$ formation. 
237 Power Block. The combined-cycle power block consisting of the $\mathrm{H}$ class gas turbine exhausts into

238 the HRSG which provides steam for the reheat steam turbine. The decarbonized syngas and the

239 depleted air from the ASU are injected into the gas turbine combustor through separate nozzles.

240 A reheat steam cycle consisting of HP steam at 166.5 bar pressure, and superheat and reheat

241 temperatures of $538^{\circ} \mathrm{C}$ is utilized. Heat is rejected from the steam turbine exhaust via a

242 mechanical draft cooling tower.

\subsection{Coproduction}

The coproducing IGCC configurations are similar to the previously described scheme for

245 electricity only except in the feed handling systems (the coproduction plants being cofed with

246 biomass), and due to the addition of the coproduction unit itself. Major differences in the

247 configuration are described in the following:

248 Air Separation. Since a significant portion of the syngas is utilized for producing the coproduct,

249 the relative size of the gasification island in relation to the power island is much larger than that

250 in the Electricity Only case. This results in the amount of air that may be extracted from the gas

251 turbine not being sufficient for the ASU, since the maximum amount that may be extracted is

252 typically limited to $50 \%$ of the total gas turbine inlet air for reasons such as not starving the gas

253 turbine combustor of its liner cooling medium. Thus, a compressor is included in the ASU to

254 supply the additional air required by the ASU. In the F-T liquids and ethanol coproduction cases,

255 the ASU provides $\mathrm{O}_{2}$ to an autothermal reformer located in the synthesis unit, in addition to the 256 gasifier and the $\mathrm{H}_{2} \mathrm{SO}_{4}$ unit.

F-T Liquids Synthesis. Once through synthesis of coproducts such as F-T liquids and

258 ethanol while supplying the unconverted gas to the gas turbine has been shown to be

259 advantageous but in the context of no CCS. These advantages include avoiding the buildup of 
inerts in the feed to the synthesis reactor, and eliminating the large recycle compressor and

261 associated equipment for the unconverted gas. Since our plant designs do require a significant

262 degree of CCS, a screening analysis is first conducted to quantify the effect of purge rate from

263 the synthesis loop on the overall system efficiency. For a F-T liquids coproduction plant, it is

264 found that the electrical heat rate is increased by as much as $1.46 \%$ when the purge rate is

265 increased to $10 \%$ of the total recycle. When the purge rate becomes higher than a threshold

266 amount, decarbonization of the purge gas is also required to limit the overall plant carbon

267 emissions to the required value. The reduction in efficiency is due to the requirement for

268 shifting and reforming the purge gas before the carbon may be captured as $\mathrm{CO}_{2}$ which creates

269 major irreversibilities from a thermodynamic standpoint. These additional equipment end up

270 also penalizing the plant cost on a net basis. It should also be noted that with the ITM

271 technology utilized for air separation in our work, the inerts buildup due to a reduction in the

272 purge rate is less significant than for a plant utilizing cryogenic air separation.

273 The resulting plant configuration is depicted in Fig. 2. A fraction of the clean syngas

274 before it enters a $2^{\text {nd }}$ shift reactor is combined with a fraction of the unshifted syngas in order to

275 obtain the specified $\mathrm{H}_{2} / \mathrm{CO}$ ratio of $\sim 1$ for the synthesis reactor feed gas, and passed through a

276 bed of $\mathrm{ZnO}$ sandwiching a COS hydrolysis catalyst to remove the trace amounts of sulfur

277 compounds present. The desulfurized syngas is then expanded through a power recovery

278 turbine to near synloop pressure (nominally at 24 barA) and combined with the synloop recycle

279 syngas. The combined stream is then cooled in a series of heat exchangers, fed to an amine

280 wash unit to remove most of the $\mathrm{CO}_{2}$, and preheated in a feed/effluent interchanger before

281 being fed to a slurry reactor with Fe based catalyst particles suspending in an inert hydrocarbon

282 liquid (a mineral oil). The mineral oil acts as a temperature moderator and a heat removal

283 medium, transferring the heat of reaction from the catalyst surface via the liquid slurry to 
284 boiling water in an internal tubular heat exchanger. IP steam is generated from the heat. The 285 major overall reactions occurring are: $(2 n+1) \mathrm{H}_{2}+n \mathrm{CO}=\mathrm{H}-\left(\mathrm{CH}_{2^{-}}\right)_{n}-\mathrm{H}+\mathrm{n} \mathrm{H}_{2} \mathrm{O}$ and $\mathrm{CO}+\mathrm{H}_{2} \mathrm{O}=$ $286 \mathrm{CO}_{2}+\mathrm{H}_{2}$. The reactor effluent at $260^{\circ} \mathrm{C}$ is cooled in a series of heat exchangers including the 287 feed/effluent interchanger. The condensate collected is fed to the product stabilization unit 288 which consists of a column to remove the dissolved light ends. The recycle gas which contains $289 \mathrm{CH}_{4}$ and other undesirable hydrocarbons (undesirable in the context of maximizing the F-T 290 liquids) is compressed and fed to an autothermal reformer to convert the hydrocarbons back to $291 \mathrm{H}_{2}$ and CO. The F-T liquids contain significant amounts of high molecular weight waxes and 292 require hydrocracking to produce lower molecular weight hydrocarbons followed by distillation 293 for separating out the naphtha, diesel, and lighter molecular weight hydrocarbon fractions. It is 294 assumed that these operations will be conducted at an existing refinery.

Ethanol Synthesis. The results obtained for the F-T liquids synthesis loop with respect to 296 minimizing the purge rate are assumed to apply to ethanol coproduction where shifting and 297 reforming of the unconverted gas is also required. The resulting plant configuration is depicted 298 in Fig. 3. As in the previous case, a fraction of the clean syngas before it enters the $2^{\text {nd }}$ shift 299 reactor is combined with a fraction of the unshifted syngas but to obtain a higher $\mathrm{H}_{2} / \mathrm{CO}$ ratio of 3002.0 at the synthesis reactor inlet. Again, the combined gas is passed through a bed of $\mathrm{ZnO}$ 301 sandwiching a COS hydrolysis catalyst to remove the trace amounts of sulfur compounds 302 present. The desulfurized syngas is then expanded through a power recovery turbine to near 303 synloop pressure which is lower in this case (14 barA at the synthesis reactor outlet) and 304 combined with the synloop recycle syngas. The combined stream after cooling in a series of heat 305 exchangers and removal of most of the $\mathrm{CO}_{2}$ in an amine wash, is preheated in a feed/effluent 306 interchanger before being fed to a fixed bed reactor containing Rh based catalyst. The 307 exothermic reaction heat is transferred to boiling water in an internal tubular heat exchanger to 
generate IP steam. The major overall reactions occurring are: $2 n \mathrm{H}_{2}+n \mathrm{CO}=\mathrm{C}_{n} \mathrm{H}_{2 n+1} \mathrm{OH}+(n-1)$

$\mathrm{H}_{2} \mathrm{O}$ (with n predominantly = 2), $3 \mathrm{H}_{2}+\mathrm{CO}=\mathrm{CH}_{4}+\mathrm{H}_{2} \mathrm{O}$ and $\mathrm{CO}+\mathrm{H}_{2} \mathrm{O}=\mathrm{CO}_{2}+\mathrm{H}_{2}$. The reactor

310 effluent at $285^{\circ} \mathrm{C}$ is cooled in a series of heat exchangers including the feed/effluent

311 interchanger. The recycle gas which contains $\mathrm{CH}_{4}$ and $\mathrm{CH}_{3} \mathrm{OH}$ is compressed and fed to an

312 autothermal reformer to convert these compounds back to $\mathrm{H}_{2}$ and $\mathrm{CO}$ in order to maximize the

313 production of the ethanol. The condensate collected is fed to the purification unit which consists

314 of a set of energy saving heat integrated distillation columns (HP and LP columns with the

315 condenser of the HP column providing heat for the reboiler of the LP column) to produce the

316 azeotropic mixture of $\mathrm{C}_{2} \mathrm{H}_{5} \mathrm{OH}$ and $\mathrm{H}_{2} \mathrm{O}$ which is then dehydrated using molecular sieves to meet

317 the required specifications.

318 Hydrogen Coproduction. As seen in the plant configuration depicted in Fig. 4, a fraction of the

$319 \mathrm{H}_{2}$ rich decarbonized syngas (after shifting and $\mathrm{CO}_{2}$ separation) before entering the power block

320 is fed to a pressure swing adsorption (PSA) unit to produce the higher purity coproduct meeting

321 the specifications as defined in the design basis. The tail gas from the PSA is compressed and

322 combined with the remaining of the decarbonized syngas and combusted in the gas turbine.

323 Coproduction of $\mathrm{H}_{2}$ is thus easily accomplished in an IGCC designed for CCS.

\section{Results and discussion}

Tables 3 and 4 summarize the plant performances for the bituminous and the lignite

326 cases. The plant feed rates for each of the cases are determined to fully load the $\mathrm{H}$ class gas

327 turbine under the site specific ambient conditions. Thermal efficiencies for the electricity only

328 cases with $90 \%$ carbon capture are $38.3 \%$ and $36.8 \%$ (HHV basis) with the bituminous and the

329 lignite feedstocks respectively, the lignite case having a lower efficiency primarily due its higher

330 moisture content. For the coproduction cases (where $50 \%$ of the energy exported is in the form 
331 of electricity), the electrical efficiency, as expected, is highest for the hydrogen coproduction

332 cases. The plant thermal efficiency reduces as a greater fraction of chemical energy contained in

333 the raw syngas is degraded to heat. In the hydrogen coproduction case, this degradation occurs

334 by the shift reaction but its exothermicity is quite small when compared to the reactions

335 occurring in the F-T as well as the ethanol synthesis reactors.

336 The electrical efficiencies for F-T coproduction cases are higher than those for the

337 ethanol coproduction cases but it should be noted that the ethanol coproduction cases produce

338 the finished coproduct while the F-T coproduction cases produce a coproduct that requires

339 further processing in a refinery. The cross comparison of the thermal performance between the

340 various coproduct cases is further complicated by the fact that the carbon footprint is not the

341 same when carbon leaving with the coproduct is accounted for. The lower efficiency of the

342 ethanol cases is partly due to a low per pass conversion ( $<10$ mole $\%$ of the $\mathrm{CO}$ and $\sim 15$ mole $\%$

343 of the recycled methanol) to ethanol (and higher alcohols) requiring a large recycle rate. The

344 thermal efficiency and consequently the overall plant economics can be enhanced if the

345 methanol formed as a side-product is not recycled to the synthesis reactor but purified and sold 346 as an additional coproduct.

347 The efficiency of both the F-T and the ethanol cases can be enhanced if the $\mathrm{CH}_{4}$ formed

348 during synthesis is sold as an additional coproduct, substitute natural gas after separation and

349 purification. The impact on plant economics however is dependent on the prevailing natural gas

350 price which is being impacted by shale gas prices. Tables 5 and 6 present the plant cost

351 estimates and results of the economic analysis for the bituminous and the lignite cases. The $1^{\text {st }}$

352 year levelized cost of electricity for each of the two Electricity Only (bituminous and lignite)

353 cases is first developed and then the coproduct cost is derived such that the same $1^{\text {st }}$ year 
354 levelized cost of electricity as the corresponding Electricity Only case (i.e., with the same coal)

355 results.

356

The first year cost of electricity calculated for the bituminous coal is $\$ 103 / \mathrm{MWh}$ while

358 that for the lignite is $\$ 108 / \mathrm{MWh}$. The calculated cost of the F-T liquids ranges from $\$ 77.8 / \mathrm{bbl}$ to

$359 \$ 86.6 / \mathrm{bbl}$ (or $\$ 0.0177$ to $0.0197 / \mathrm{MJ}$ LHV) depending on the feedstock. The cost of the fuel grade

360 ethanol ranges from $\$ 4.84 /$ gal to $\$ 4.91 /$ gal, while it ranged from $\$ 2.20 /$ gal to $\$ 3.70 /$ gal in a DoE

361 funded study conducted by Louisiana State University [DOE Award: DE-FC26-06NT43024]. The

362 Louisiana State University study consisted of a significantly larger plant than our study and

363 benefited from economies of scale. When the plant size in our study is scaled up to similar size

364 as in the Louisiana State University study, cost of alcohol is then reduced to a range of \$3.24/gal

365 to $\$ 4.28 /$ gal, which is comparable. The cost of hydrogen ranges from $\$ 1.87 / \mathrm{kg}$ to $\$ 2.13 / \mathrm{kg}$. In all

366 cases, the coproduct cost is lower for the bituminous coal cofed plants than the lignite cofed

367 plants.

368

369

370

5. Summary and conclusions

371 could be refined in existing refineries while displacing petroleum and the refined products

372 introduced into the market place at the present time or in the near term without requiring any

373 changes to the existing infrastructure, ethanol could potentially serve in the not so distant

374 future (or phased in by blending with conventional liquid fuels), and hydrogen which could be

375 the fuel of the future being especially suitable to the FCHV. Two types of coal (bituminous and

376 lignite) along with switchgrass as the biomass cofeed are included. Among the coproduction

377 cases, the electrical efficiency as expected is highest for the hydrogen coproduction. The 
378 electrical efficiency for F-T coproduction is higher than that for the ethanol coproduction but it

379 should be noted that the ethanol coproduction plants produce the finished coproduct while the

380 F-T coproduction plants produce a coproduct that requires further processing in a refinery. The

381 cross comparison of the thermal performance between the various coproduct cases is further

382 complicated by the fact that the carbon footprint is not the same when carbon leaving with the

383 coproduct is accounted for. The F-T liquids cost is comparable to the current market price of

384 crude oil. It should be noted, however, that F-T liquids contain no sulfur or nitrogen compounds

385 and no inorganics. The cost of the ethanol is higher than the current price of gasoline in the U.S.,

386 and thus the ethanol coproduction may not appear to be as attractive as the other options at

387 these scales, primarily due to the much lower plant efficiency. However, from a life cycle

388 greenhouse gas emissions standpoint, ethanol produced with biomass cofeeding and CCS, have

389 a lower carbon footprint than gasoline or diesel, especially when derived from petroleum. The

390 calculated cost of hydrogen is significantly lower than the DoE announced goal of $\$ 3.00 / \mathrm{kg}$ in

3912005.

\section{Acknowledgements}

The authors wish to acknowledge the U.S. DoE and the National Energy Technology

395 Laboratory under whose sponsorship the Advanced Power and Energy Program of the University

396 of California, Irvine conducted most of this study (Contract No. DE-FE0005376). Neither the

397 United States Government nor any agency thereof, nor any of their employees, makes any

398 warranty, express or implied, or assumes any legal liability or responsibility for the accuracy,

399 completeness, or usefulness of any information, apparatus, product, or process disclosed, or

400 represents that its use would not infringe privately owned rights. Reference herein to any

401 specific commercial product, process, or service by trade name, trademark, manufacturer, or 
otherwise does not necessarily constitute or imply its endorsement, recommendation, or

403 favoring by the United States Government or any agency thereof. The views and opinions of

404 authors expressed herein do not necessarily state or reflect those of the United States

405 Government or any agency thereof.

\section{References}

408 [1] Lafakis C. Moody's Analytics. http://money.cnn.com/2015/01/09/investing/oil-price409 bottom/index.html (accessed on 1-12-15).

410 [2] Conti J, Holtberg P. International Energy Outlook 2013. Energy Information

411 Administration (EIA); 2013.

412 [3] September 2013 Monthly Energy Review. U.S. Energy Information Administration.

413 http://www.eia.gov/totalenergy/data/monthly/\#environment (accessed on 10-10-13).

414 [4] Rao AD, Samuelsen GS, Yi Y. Gas Turbine Based High-efficiency 'Vision 21' Natural Gas

415 and Coal Central Plants. Proceedings of the Institution of Mechanical Engineers, Part A: Power

416 and Energy 2005;219(2):127-36.

417 [5] Li M, Rao AD, Scott Samuelsen G. Performance and costs of advanced sustainable

418 central power plants with CCS and $\mathrm{H}_{2}$ co-production. Applied Energy 2012;91(1):43-50.

419 [6] Cormos CC. Hydrogen and power co-generation based on coal and biomass/solid wastes

420 co-gasification with carbon capture and storage. International Journal of Hydrogen Energy

$421 \quad 2012 ; 37(7): 5637-48$.

422 [7] Cory KS, Swezey BG. Renewable Portfolio Standards in the States: Balancing Goals and

423 Implementation Strategies. National Renewable Energy Laboratory/US Department of Energy

424 Technical Report, NREL/TP-670-41409; December 2007.

425 [8] California Energy Commission. www.energy.ca.gov (accessed on 10-10-13).

426 [9] Siemens Fuel Gasification Technology. Siemens Energy Sector.

427

428

429

430

431

432

433

434

435

436

http://www.energy.siemens.com.cn/CN/downloadCenter/Documents/E $F$ fuel gasifier en.pdf (accessed on 10-10-13); 2008.

[10] van der Ploeg HJ, Chhoa T, Zuideveld PL. The Shell Coal Gasificaion Process for the US Industry. Gasification Technology Conference. Washington DC, USA; Octorber 2004.

[11] Repasky JM, Foster EP, Armstrong PA, Stein VE, Anderson LL. ITM Oxygen Development for Advanced Oxygen Supply. Gasification Technologies Council. San Francisco, California, USA; October 12, 2011.

[12] Rosen L, Degenstein N, Shah M, Wilson J, Kelly S, Peck J, Christie M. Development of oxygen transport membranes for coal-based power generation. Energy Procedia 2011;4(0):7505.

437 [13] Siriwardane RV, Cicero DC, Jain S, Raghubir, Gupta P, Turk BS. Durable Zinc Oxide-Based 438 Regenerable Sorbents for Desulfurization of Syngas in a Fixed-Bed Reactor. Fifth international 439 symposium on gas cleaning at high temperature; September 17-20, 2002. 
[14] Alptekin G, Dietz S, Jayaraman A, Dubovik M, Amalfitano R. A Low Cost, High Capacity Regenerable Sorbent for $\mathrm{CO}_{2}$ Capture. A\&WMA's $102^{\text {nd }}$ Annual Conference \& Exhibition. Detroit, MI, USA; June 16-19, 2009

443 [15] Rao AD, Francuz DJ. An evaluation of advanced combined cycles. Applied Energy

[16] Neathery J, Gray D, Challman D, Derbyshire F. The pioneer plant concept: co-production of electricity and added-value products from coal. Fuel 1999; 78(7):815-823.

[17] Chiesa P, Consonni S, Kreutz T, Williams R. Co-production of hydrogen, electricity and $\mathrm{CO} 2$ from coal with commercially ready technology. Part A: Performance and emissions. International Journal of Hydrogen Energy 2005; 30(7):747-767.

[18] Zhou L, Hu S, Li Y, Zhou Q. Study on co-feed and co-production system based on coal and natural gas for producing DME and electricity. Chemical Engineering Journal 2008; 136(1):31-40.

[19] Wenguo $X$, Yingying C. Hydrogen and electricity from coal with carbon dioxide separation using chemical looping reactors. Energy \& Fuels 2007; 21(4):2272-2277.

[20] Zhou L, Hu S, Li Y, Zhou Q. Study on co-feed and co-production system based on coal and natural gas for producing DME and electricity. Chemical Engineering Journal 2008; 136(1):31-40.

[21] Larson ED, Jin H, Celik FE. Large - scale gasification - based coproduction of fuels and electricity from switchgrass. Biofuels, Bioproducts and Biorefining 2009; 3(2):174-194.

[22] Xiang W, Chen S, Xue Z, Sun X. Investigation of coal gasification hydrogen and electricity co-production plant with three-reactors chemical looping process. International Journal of Hydrogen Energy 2010; 35(16):8580-8591.

[23] Different Coal Ranks. The National Energy Technology Laboratory (NETL). http://www.netl.doe.gov/technologies/coalpower/gasification/gasifipedia/coal.html (accessed on 10-10-13).

[24] Advanced Gasification: Novel CO2 Utilization Systems, Low Rank Coal IGCC Optimization, and Improvements in Gasification Systems Availability and Costs. DoE Funding Opportunity Number: DE-FOA0000496, March 15, 2011.

[25] Matuszewski M. Greenhouse Gas Reductions in the Power Industry Using Domestic Coal and Biomass - Volume 1: IGCC. DOE/NETL-2012/1546 February 2012.

[26] van Holthoon E. Shell Gasification Processes. Gasification Technology Conference. San Francisco, California, USA; 2007.

[27] Carpenter DL, Bain RL, Davis RE, Dutta A, Feik CJ, Gaston KR, Jablonski W, Phillips SD, Nimlos MR. Pilot-scale gasification of corn stover, switchgrass, wheat straw, and wood: 1. Parametric study and comparison with literature. Ind Eng Chem Res 2010;49(4):1859-71. [28] Conservation Reserve Program. Farm Service Agency, the U.S. Department of Agriculture. http://www.fsa.usda.gov/FSA/webapp?area=home\&subject=copr\&topic=crp (accessed 09-25-13).

[29] Chen Q, Rao A, Samuelsen S. $\mathrm{H}_{2}$ coproduction in IGCC with CCS via coal and biomass mixture using advanced technologies. Applied Energy 2014;118:258-270.

[30] Armstrong P. Method for Predicting Performance of an lon Transport Membrane UnitOperation. Air Products and Chemicals Inc, Pennsylvania, USA 2002.

[31] Bishop B, Raskin N. CeraMem Filter Development Program. Advanced Coal-Fired Power Systems '96 Review Meeting. Morgantown, West Virginia, USA; 1996.

[32] Alptekin G, Lind J, Amalfitano R, Copeland R. Sorbents for Mercury Removal from CoalDerived Synthesis Gas. Twentieth Annual International Pittsburgh Coal Conference, Pittsburgh, PA.: 2003; 2003. 
[33] Copeland RJ, Alptekin G, Cessario M, Gebhard S, Gerhanovich Y. A novel CO2 separation system. The Eighth International Symposium on Transport Phenomena and Dynamics of

490 Rotating Machinery. Honolulu, HI, USA; 2000.

491 [34] Crocker CR, Benson SA, Holmes MJ, Zhuang Y, Pavlish JH, Galbreath KC. Comparison of 492 sorbents and furnace additives for mercury control in low-rank fuel combustion systems. Prepr 493 Pap-Am Chem Soc, Div Fuel Chem 2004; 49(1):289.

494 [35] Lemus R, Brummer EC, Moore KJ, Molstad NE, Burras CL, Barker MF. Biomass yield and 495 quality of 20 switchgrass populations in southern lowa, USA. Biomass and Bioenergy 496 2002;23(6):433-42.

497 [36] Black J. Cost and Performance Baseline for Fossil Energy Plants Volume 1: Bituminous 498 Coal and Natural Gas to Electricity. DOE/NETL-2010/1397; November 2010.

499 [37] Black J. Cost and Performance Baseline for Fossil Energy Plants Volume 3a: Low Rank Coal 500 to to Electricity: IGCC CASES. DOE/NETL Report 2010/1399; May 2011

501 [38] Bonk DL, Hay A. Stamet Solids Pump Feeds Coal into 210 psig in a DOE Supported 502 Project. DOE/METC/C-96/7208; 1995.

503 [39] Aldred D, Saunders T, Shirey G. Results of DOE Funded Research to Achieve Continuous 504 Injection of Solid Fuels into Advanced Combustion and Gasification System Pressures. 2003 505 Gasification Technology Conference; Octorber 12, 2003.

506 [40] Bechtel Group, Inc. Slurry Reactor Design Studies: Slurry vs. Fixed-Bed Reactors for 507 Fischer-Tropsch and Methanol; Final Report. DoE contract DE-AC22-89PC89867, Pittsburgh 508 Energy Technology Center; 1990.

509 [41] Spivey JJ, Egbebi A. Heterogeneous catalytic synthesis of ethanol from biomass-derived 510 syngas. Chemical Society Reviews 2007; 36(9):1514-1528.

511 [42] Rao AD, Francuz DJ. An evaluation of advanced combined cycles. Applied Energy 2013; 512 102:1178-1186.

513 [43] Rao AD, Chen Q, Samuelsen GS. Design Concepts for Co-Production of Power, Fuels \& 514 Chemicals Via Coal/Biomass Mixtures. Final Report DE-FE0005376; September 30, 2012 515 (http://www.osti.gov/scitech/biblio/1082145). 


\section{FIGURE CAPTIONS}

Fig.1. Block Flow Diagram - Electricity Only IGCC Plants with CCS (stream data in [43])

Fig.2. Block Flow Diagram - Electricity and Fischer Tropsch Liquids Coproduction IGCC Plants CCS (stream data in [43])

Fig.3. Block Flow Diagram - Electricity and Ethanol Coproduction IGCC Plants CCS (stream data in [43])

Fig.4.Block Flow Diagram - Electricity and $\mathrm{H}_{2}$ Coproduction IGCC Plants CCS (stream data in [43]) 


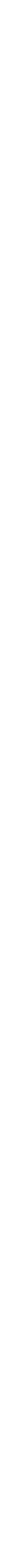




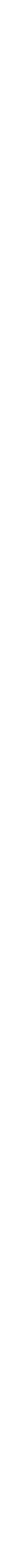




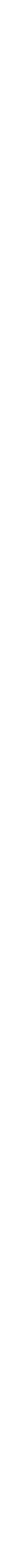



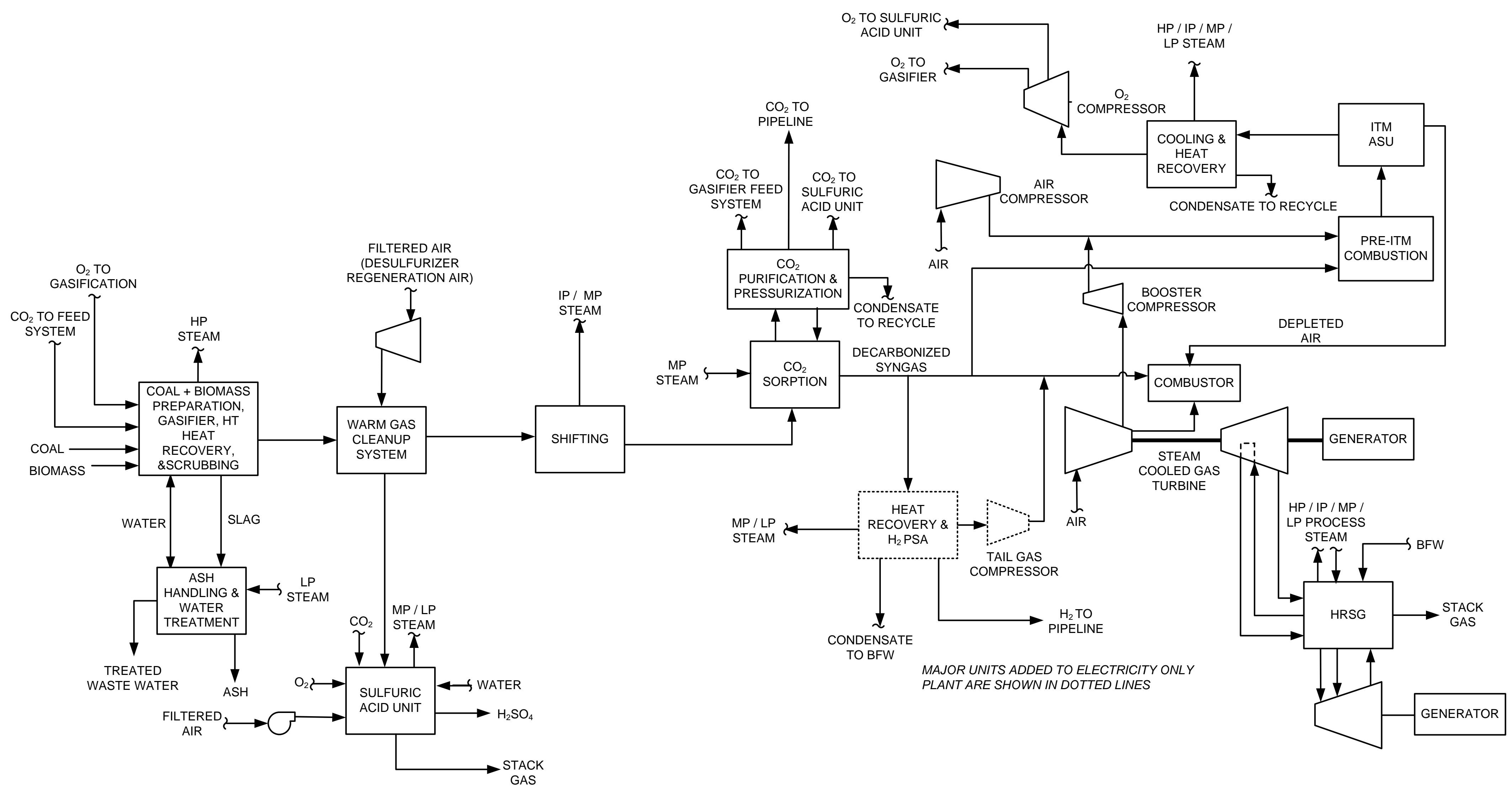
Table 1 Coal and Biomass Properties

\begin{tabular}{|l|r|r|r|r|r|r|}
\hline & \multicolumn{2}{|c|}{$\begin{array}{l}\text { Illinois No. 6 } \\
\text { Bituminous }\end{array}$} & \multicolumn{2}{c|}{ N. Dakota Lignite } & \multicolumn{2}{c|}{ Switchgrass Biomass } \\
\cline { 2 - 7 } & $\begin{array}{l}\text { Dry } \\
\text { Basis, \% }\end{array}$ & $\begin{array}{l}\text { As } \\
\text { Received, \% }\end{array}$ & Dry Basis, \% & \multicolumn{1}{l|}{$\begin{array}{l}\text { As } \\
\text { Received, \% }\end{array}$} & $\begin{array}{c}\text { Dry } \\
\text { Basis, \% }\end{array}$ & $\begin{array}{c}\text { As } \\
\text { Received, \% }\end{array}$ \\
\hline Carbon & 71.72 & 63.75 & 61.88 & 39.55 & 42.60 & 36.21 \\
\hline Hydrogen & 5.06 & 4.5 & 4.29 & 2.74 & 6.55 & 5.57 \\
\hline Nitrogen & 1.41 & 1.25 & 0.98 & 0.63 & 1.31 & 1.11 \\
\hline Sulfur & 2.82 & 2.51 & 0.98 & 0.63 & 0.01 & 0.01 \\
\hline Chlorine & 0.33 & 0.29 & 18 ppmw [34] & 12 ppmw [34] & $0.04[35]$ & $0.03[35]$ \\
\hline Ash & 10.91 & 9.7 & 15.43 & 9.86 & 7.41 & 6.30 \\
\hline Moisture & 0.00 & 11.12 & 0.00 & 36.08 & 0.00 & 15.00 \\
\hline Oxygen & 7.75 & 6.88 & 16.44 & 10.51 & 42.08 & 35.77 \\
\hline Total & 100 & 100 & 100 & 100 & 100.00 & 100.00 \\
\hline HHV, kJ/kg & 30,531 & 27,135 & 24,253 & 15,391 & 18,113 & 15,396 \\
\hline LHV, kJ/kg & 29,568 & 26,172 & 23,334 & 14,803 & 16,659 & 14,161 \\
\hline Mercury, ppm & & $0.18[36]$ & & 0.116 & & \\
\hline
\end{tabular}


Table 2 Advanced technologies selected

\begin{tabular}{|c|c|c|}
\hline Plant subsection & Technology & Comments \\
\hline Air Separation & ITM & Being developed by Air Products and Praxair $[11,12]$ \\
\hline Biomass Pretreatment & $\begin{array}{l}\text { Drying using vapor recompression and size reduction by } \\
\text { milling }\end{array}$ & $\begin{array}{l}\text { Co-feeding biomass with coal into a pressurized dry feed (Shell) gasifier at proposed levels } \\
\text { demonstrated at Nuon IGCC (particle size }<1 \mathrm{~mm} \text { ) [26]. Experimental data for hammer } \\
\text { mill power for switchgrass with } 6-12 \% \text { moisture available. Milling power not a significant } \\
\text { impact on plant thermal performance. }\end{array}$ \\
\hline Gasifier feeding & Solids pump & $\begin{array}{l}\text { Using recycle } \mathrm{CO}_{2} \text { as inerting and injection gas. Maximum discharge pressure limited to } \\
8.3 \mathrm{MPa}(1200 \mathrm{psi}) \text { based on } \mathrm{PW} \text { gasifier demonstration program }[38,39] .\end{array}$ \\
\hline Gasifier & $\begin{array}{l}\text { Siemens type dry-feed entrained-bed operating at } \\
\text { commercially offered operation pressure of } \sim 41 \text { bar ( } 600 \mathrm{psi} \text { ) } \\
\text { and not at higher unproven pressure }\end{array}$ & $\begin{array}{l}\text { Siemens gasifier with multiple feed nozzles is available [9]. The operating pressure of the } \\
\text { Siemens gasifier for current projects is } 4 \mathrm{MPa} \text { while their patents site a maximum pressure } \\
\text { of } 10 \mathrm{MPa} \text {. }\end{array}$ \\
\hline Syngas Desulfurization & Humid gas cleanup using RTI's $\mathrm{ZnO}$ treating process & Regenerable process while producing $\mathrm{H}_{2} \mathrm{SO}_{4}$ from the regenerator off-gas [13]. \\
\hline Syngas Mercury Removal & Humid gas cleanup using TDA's process & A "throw away" process, $\mathrm{Hg}$ content of feedstock being low [32]. \\
\hline Syngas Shifting & Sulfur tolerant catalyst & $\begin{array}{l}\text { Adiabatic beds with intercooling in series depending on the degree of shifting required } \\
\text { with bypass control for } \mathrm{CO} \text { to } \mathrm{H}_{2} \text { ratio [36]. }\end{array}$ \\
\hline Syngas $\mathrm{CO}_{2}$ Separation & $\begin{array}{l}\text { Humid gas cleanup using absorption beds such as the TDA } \\
\text { process }\end{array}$ & Regenerable process using steam to strip off the $\mathrm{CO}_{2}[14,33]$. \\
\hline F-T Synthesis & Slurry reactor containing Fe based catalyst & $\mathrm{H} 2 / \mathrm{CO}$ molar ratio of 1 in feed gas [40]. \\
\hline Ethanol Synthesis & $\begin{array}{l}\text { Fixed bed reactor containing Rh based catalyst to synthesize } \\
\text { primarily ethanol }\end{array}$ & $\mathrm{H} 2 / \mathrm{CO}$ molar ratio of 2 in feed gas [41]. \\
\hline Power Island & $\mathrm{H}$ class gas turbine based combined cycle & $\begin{array}{l}\text { It is assumed that this type of gas turbine will be offered for syngas applications in the } \\
\text { time frame of these advanced gasification plants. Firing temperature of the gas turbine }\end{array}$ \\
\hline
\end{tabular}


Table 3 Plant thermal performance - bituminous coal cases

\begin{tabular}{|c|c|c|c|c|c|}
\hline Cofeed & & None & \multicolumn{3}{|c|}{ Switchgrass } \\
\hline Coproduct & Units & None & F-T Liquids & Ethanol & Hydrogen \\
\hline Coal feed rate & tonne/D (dry) & 2,950 & 3,060 & 3,290 & 3,350 \\
\hline Biomass feed rate & tonne/D (dry) & - & 1,310 & 1,410 & 1,440 \\
\hline Total HHV input & $\mathrm{GJ} / \mathrm{h}$ & 3,750 & 4,890 & 5,240 & 5,350 \\
\hline $\begin{array}{l}\text { Gas turbine power } \\
\text { output }\end{array}$ & $\mathrm{MW}$ & 318 & 318 & 318 & 318 \\
\hline $\begin{array}{l}\text { Steam turbine power } \\
\text { output }\end{array}$ & $\mathrm{MW}$ & 147 & 167 & 126 & 166 \\
\hline $\begin{array}{l}\text { Total gross power } \\
\text { output }\end{array}$ & MW & 465 & 485 & 444 & 484 \\
\hline $\begin{array}{l}\text { Total auxiliary } \\
\text { consumption }\end{array}$ & MW & 66 & 160 & 222 & 112 \\
\hline $\begin{array}{l}\text { Net electric power } \\
\text { output }\end{array}$ & MW & 399 & 325 & 222 & 372 \\
\hline $\begin{array}{l}\text { Net electric power } \\
\text { efficiency, HHV }\end{array}$ & $\%$ & 38.3 & 24.0 & 15.3 & 25.0 \\
\hline Coproduct produced & tonne/D & - & 593 & 621 & 226 \\
\hline Coproduct HHV & $\mathrm{GJ} / \mathrm{h}$ & - & 1,160 & 792 & 1,340 \\
\hline $\begin{array}{l}\text { Electricity/( Electricity + } \\
\text { Coproduct HHV) }\end{array}$ & $\%$ & 100 & 50 & 50 & 50 \\
\hline Carbon captured & $\%$ & 90.0 & 80.0 & 80.0 & 80.0 \\
\hline Surface condenser duty & $\mathrm{GJ} / \mathrm{h}$ & 686 & 922 & 457 & 803 \\
\hline Raw water use & $\mathrm{M}^{3} / \mathrm{m}$ & 13.2 & 17.6 & 18.7 & 16.0 \\
\hline
\end{tabular}


Table 4 Plant thermal performance - lignite cases

\begin{tabular}{|c|c|c|c|c|c|}
\hline \multirow{2}{*}{$\begin{array}{l}\text { Cofeed } \\
\text { Coproduct }\end{array}$} & \multirow[b]{2}{*}{ Units } & \multirow{2}{*}{$\begin{array}{l}\text { None } \\
\text { None }\end{array}$} & \multicolumn{3}{|c|}{ Switchgrass } \\
\hline & & & F-T Liquids & Ethanol & Hydrogen \\
\hline Coal feed rate & tonne/D (dry) & 3,620 & 3,370 & 3,650 & 3,630 \\
\hline Biomass feed rate & tonne/D (dry) & - & 1,440 & 1,560 & 1,560 \\
\hline Total HHV input & $\mathrm{GJ} / \mathrm{h}$ & 3,660 & 4,500 & 4,870 & 4,850 \\
\hline Gas turbine power output & MW & 313 & 313 & 313 & 313 \\
\hline $\begin{array}{l}\text { Steam turbine power } \\
\text { output }\end{array}$ & $\mathrm{MW}$ & 141 & 154 & 121 & 150 \\
\hline Total gross power output & MW & 454 & 467 & 434 & 463 \\
\hline Total auxiliary consumption & MW & 80 & 179 & 226 & 137 \\
\hline Net electric power output & MW & 374 & 288 & 208 & 326 \\
\hline $\begin{array}{l}\text { Net electric power } \\
\text { efficiency, HHV }\end{array}$ & $\%$ & 36.8 & 23.0 & 15.4 & 24.2 \\
\hline Coproduct produced & tonne/D & - & 529 & 586 & 198 \\
\hline Coproduct HHV & $\mathrm{GJ} / \mathrm{h}$ & - & 1,030 & 748 & 1,170 \\
\hline $\begin{array}{l}\text { Electricity/( Electricity + } \\
\text { Coproduct HHV) }\end{array}$ & $\%$ & 100 & 50 & 50 & 50 \\
\hline Carbon captured & $\%$ & 90.0 & 80.0 & 80.0 & 80.0 \\
\hline Surface condenser duty & $\mathrm{GJ} / \mathrm{h}$ & 627 & 808 & 415 & 697 \\
\hline Raw water use & $\mathrm{M}^{3} / \mathrm{m}$ & 12.9 & 16.0 & 17.0 & 14.6 \\
\hline
\end{tabular}


Table 5 Plant cost estimates and economics - bituminous coal cases

\begin{tabular}{|c|c|c|c|c|}
\hline \multirow{2}{*}{$\begin{array}{l}\text { Cofeed } \\
\text { Coproduct }\end{array}$} & \multirow{2}{*}{$\begin{array}{l}\text { None } \\
\text { None }\end{array}$} & \multicolumn{3}{|c|}{ Switchgrass } \\
\hline & & F-T Liquids & Ethanol & Hydrogen \\
\hline \multicolumn{5}{|l|}{ Feedstock Costs, $\$ /$ dry tonne } \\
\hline Bituminous Coal [36] & \multicolumn{4}{|c|}{42} \\
\hline Switchgrass* & & \multicolumn{3}{|c|}{99} \\
\hline Net Power, MW & 399 & 325 & 222 & 372 \\
\hline \multicolumn{5}{|l|}{ Plant Cost, $\$ 10^{6}$} \\
\hline Fuel Preparation System & 147 & 195 & 205 & 207 \\
\hline Air Separation Unit & 42 & 52 & 61 & 53 \\
\hline Gasification System & 320 & 386 & 406 & 410 \\
\hline Gas Cleanup and Conditioning Systems & 267 & 201 & 208 & 316 \\
\hline Power Island & 185 & 188 & 184 & 190 \\
\hline Co-production Unit & - & 118 & 446 & 11 \\
\hline General Facilities & 156 & 166 & 164 & 173 \\
\hline Total Plant Cost (TPC), $\$ 10^{6}$ & 1,117 & 1,306 & 1,674 & 1,360 \\
\hline Total Fixed Operating Cost for Initial Year, $\$ 10^{6} / \mathrm{yr}$ & 45 & 54 & 67 & 54 \\
\hline Total Variable Operating Costs, $\$ 10^{6} / \mathrm{yr}$ & 71 & 121 & 138 & 135 \\
\hline 1st Year Cost of Electricity (COE), \$/MWh** & \multicolumn{4}{|c|}{103} \\
\hline Coproduct Cost for Initial Year, \$/kg & - & $\$ 77.8 / \mathrm{bbl}$ & $\$ 4.91 /$ gal & $\$ 1.83 / \mathrm{kg}$ \\
\hline
\end{tabular}

* Switchgrass Cost $(\$ /$ dry tonne $)=\left(1.286 * 10^{-11} * X^{3}-3.028 * 10^{-7} * X^{2}+3.569 * 10^{-3} * X+85.32\right) * 1.1025$, where $X=$ switchgrass production rate $=$ feed rate, dry ST/day [25]. The cost for each case was found to be essentially constant due to the small variation in the feed rate and was held constant.

** Methodology consistent with [36]. 
Table 6 Plant cost estimates and economics - lignite cases

\begin{tabular}{|c|c|c|c|c|}
\hline \multirow{2}{*}{$\frac{\text { Cofeed }}{\text { Coproduct }}$} & \multirow{2}{*}{$\begin{array}{l}\text { None } \\
\text { None }\end{array}$} & \multicolumn{3}{|c|}{ Switchgrass } \\
\hline & & F-T Liquids & Ethanol & Hydrogen \\
\hline \multicolumn{5}{|l|}{ Feedstock Costs, \$/dry tonne } \\
\hline Lignite [36] & \multicolumn{4}{|c|}{12} \\
\hline Switchgrass $^{\#}$ & & \multicolumn{3}{|c|}{99} \\
\hline Net Power, MW & 374 & 288 & 208 & 326 \\
\hline \multicolumn{5}{|l|}{ Plant Cost, $\$ 10^{6}$} \\
\hline Fuel Preparation System & 213 & 246 & 261 & 259 \\
\hline Air Separation Unit & 44 & 51 & 59 & 52 \\
\hline Gasification System & 328 & 377 & 398 & 395 \\
\hline Gas Cleanup and Conditioning Systems & 252 & 173 & 183 & 280 \\
\hline Power Island & 180 & 181 & 178 & 181 \\
\hline Co-production Unit & - & 109 & 384 & 10 \\
\hline General Facilities & 154 & 160 & 159 & 166 \\
\hline Total Plant Cost (TPC), $\$ 10^{6}$ & 1,171 & 1,297 & 1,622 & 1,343 \\
\hline Total Fixed Operating Cost for Initial Year, $\$ 10^{6} / \mathrm{yr}$ & 47 & 53 & 65 & 53 \\
\hline Total Variable Operating Costs, $\$ 10^{6} / \mathrm{yr}$ & 57 & 101 & 116 & 111 \\
\hline 1st Year Cost of Electricity (COE), \$/MWh ${ }^{\# \#}$ & \multicolumn{4}{|c|}{108} \\
\hline Coproduct Cost for Initial Year, \$/kg & - & $\$ 86.6 / \mathrm{bbl}$ & $\$ 4.84 /$ gal & $\$ 2.08 / \mathrm{kg}$ \\
\hline
\end{tabular}

${ }^{\#}$ Switchgrass Cost $(\$ /$ dry tonne $)=\left(1.286 * 10^{-11} * X^{3}-3.028 * 10^{-7} * X^{2}+3.569 * 10^{-3} * X+85.32\right) * 1.1025$, where $X=$ switchgrass production rate $=$ feed rate, dry ST/day [25]. The cost for each case was found to be essentially constant due to the small variation in the feed rate and was held constant.

\#\# Methodology consistent with [36]. 